\title{
Innovations Impact on Efficiency of European Railway Companies
}

UDC: 005.591.6:656.2(4)"2009/2013" $005.642 .4: 656.2$

DOI: 10.7595/management.fon.2016.0011

\begin{abstract}
The aim of this paper is the assessment of innovations impact on European railways efficiency. In order to achieve sustainable transportation development, the key challenge is modal shift from road to rail, and development of single European transport market. Innovations in the railway transport sector contribute to the higher efficiency of transport services and promoting a more competitive and resource-efficient transport system. In the first stage of this study, efficiency scores are obtained through the use of Data Envelopment Analysis (DEA), and the ranking of 23 railway companies for the time period from 2009 to 2013 is conducted. In the second stage, factors representing technological and organizational innovations are introduced. Using different statistical tests the impact of these factors on railways technical efficiency (TE) is analyzed. Results showed significant impact of innovations on efficiency level of railway companies. This paper considers most recent time period, thus enabling observation of current trends in European railway transport market. Innovations observed in this study represent key elements in the field of technological development and the structural organization of railways, with the aim of achieving sustainable European rail transport system.
\end{abstract}

Keywords: Railways, Innovations, Efficiency, Data Envelopment Analysis

\section{Introduction}

Transport plays an important role in the economic development of each country. All industries are largely dependent on the level of efficiency of the transport system. Ultimately, the development and efficiency of the transport system greatly influences the quality of people's lives. The European Union (EU) and the rest of the world are faced with serious problems such as constantly increasing in demand, pollution, climate changes and limited resources of conventional fuels.

In order to face and overcome aforementioned problems, the EU undertakes huge efforts in promoting and achieving sustainable development in transportation sector. Number of initiatives and measures are introducing in order to achieve a more competitive and resource-efficient transport system. The key challenge is modal shift from road to rail and the creation of Single European Railway Area (SERA). In that sense, one of initiatives in the EU is development of Trans-European Transport Network (TEN-T) through nine core network corridors. Shift2Rail ${ }^{1}$ initiative involves major European railway actors and aims to increase competitiveness of the railway sector in mid-long term.

Since share of rail on European passenger and freight transportation markets is still very low compared to road transportation, it is necessary to constantly improve railway transportation service through implementation of different technological and organizational solutions. To achieve an efficient European railway transport market, it is necessary for every single national market to face the challenge of efficiency improvement. In that sense, this paper aims to investigate the impact of innovations on European railways technical efficiency.

The definition of innovate from the online Oxford Dictionaries is: "Make changes in something established, especially by introducing new methods, ideas, or products". Following this definition, this study discusses the two types of innovation: (ii) technological innovation, and (ii) structural reform and railways industrial restructuring. 
This paper is organized as follows. Efficiency assessment of European railway companies is conducted and presented after the Introduction, in the Section 2 of this paper. Analysis of innovations impact on European railways efficiency is presented in the Section 3. The conclusions of this study are given in the Section 4.

\section{Efficiency assessment of European railway companies}

This paper analyzes technical efficiency of European railway companies from larger Europe during the time period of five years, between 2009 and 2013. For this aim the Data Envelopment Analysis (DEA) is selected, as the most suitable and most widely used in transportation sector efficiency assessment. Literature surveys of Liu et al. (2013a \& 2013b) as well as that of Liu et al. (2016) concluded that transportation and railways have important role in the discipline development of DEA applications.

\subsection{Defining input data}

Data set includes 23 national railway companies from larger Europe (Table 1). The data were obtained from the official UIC statistics ${ }^{2}$. Only companies which provide both, passenger and freight transportation, are selected. As infrastructure maintenance and all transportation activities have been performed as integrated for some firms, the values have been taken as they are when compiling the data; and as infrastructure maintenance and transportation activities have been separated for some firms, the respective values have been taken from different companies considering the relations among the companies (e.g. in case of Romania - companies CFR, CFR Calatori and CFR Marfa, which perform infrastructure maintenance, passenger and freight transportation service, respectively) and completed by processing for the firm which has been studied [11]. Companies from Denmark (DSB), Netherlands (NS), Norway (NSB) and Sweden (SJ AB) provide only passenger transportation service, thus they are omitted in the analysis. Also, due to the lack of data for the time period observed, companies from Estonia (EVR), Greece (OSE), Hungary (MAV), Ireland (CIE), Latvia (LDZ) and Ukraine (UZ) are excluded.

Table 1: Railway companies included in the analysis

\begin{tabular}{|l|l|l|}
\hline \multicolumn{1}{|c|}{ Country } & \multicolumn{1}{c|}{ Abbreviation } & \multicolumn{1}{c|}{ Name of the company (DMU) } \\
\hline Austria & OBB & Österreichische Bundesbahnen \\
\hline Belarus & BC & Belarus Railways \\
\hline Belgium & SNCB/NMBS & Société Nationale des Chemins de fer Belges \\
\hline Bulgaria & BDZ & Bulgarian Railways \\
\hline Croatia & HZ & Hrvatske Željeznice \\
\hline Czech Republic & CD & České dráhy \\
\hline Finland & VR & VR-Group Ltd \\
\hline France & SNCF & Société Nationale des Chemins de fer Français \\
\hline Germany & DBAG & Deutsche Bahn AG \\
\hline Italy & FS & Ferrovie dello Stato SpA \\
\hline Lithuania & LG & SPAB “Lietuvos Gelezinkeliai” \\
\hline Luxembourg & CFL & Société Nationale des Chemins de Fer Luxembourgeois \\
\hline Macedonia & MZ & Makedonski Železnici \\
\hline Moldova & CFM & Calea Ferată din Moldova \\
\hline Poland & PKP & Polskie Koleje Panstwowe S.A. \\
\hline Portugal & CP & Caminhos de Ferro Portugueses \\
\hline Romania & CFR & Căile Ferate Române \\
\hline Serbia & ZS & Železnice Srbije \\
\hline Slovak Republic & ZSSK ZSR & Slovak Rail Železnice Slovenskej Republiky \\
\hline Slovenia & SZ & Slovenske Železnice d.d. \\
\hline Spain & RENFE & Red Nacional de los Ferrocarriles Españoles \\
\hline Switzerland & SBB CFF FFS & Schweizerische Bundesbahnen \\
\hline Turkey & TCDD & Türkiye Cumhuriyeti Devlet Demiryollari Isletmesi \\
\hline
\end{tabular}

\footnotetext{
${ }^{2}$ UIC (International Union of Railways), Railisa Database, Available on: http://www.uic.org/statistics
} 
Four input and two output variables that characterize railways transportation process are employed in this paper (Figure 1). Input variables include total length of lines, total number of employees, number of passenger cars and number of freight wagons. Two output variables which represent revenue measures are passenger-kilometers and freight ton-kilometers.

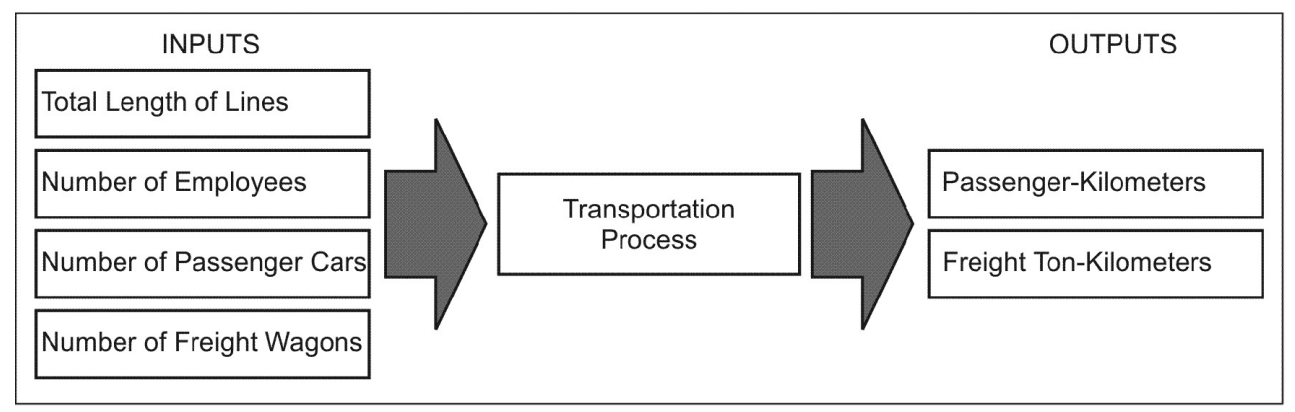

Figure 1: Inputs and outputs in DEA model

Although there are studies which analyze passenger and freight transportation efficiency separately (e.g. Hilmola, 2008; Yu \& Lin, 2008), this paper aims to conduct overall efficiency assessment of European railways, thus all variables are integrated into a single model. Also, some authors included additional inputs and outputs, such as number of locomotives, number of passengers carried, freight tons transported (e.g. Hilmola, 2008; Kutlar et al., 2013), passenger and freight train-kilometers (Oum \& Yu, 1994; Yu \& Lin, 2008). These variables are not included in this study, since only factors which affect railway transportation process the most and which represent revenue measures are observed. Descriptive statistics of inputs and outputs selected for the time period observed are presented in Table 2.

Table 2: Descriptive statistics of inputs and outputs in DEA model

\begin{tabular}{|l|l|l|c|c|c|c|c|}
\hline Var. & \multicolumn{1}{|c|}{ Description } & \multicolumn{1}{c|}{ Unit } & Obs. & Mean & Min & Max & Std.Dev. \\
\hline $\mathbf{x}_{\mathbf{1}}$ & Total length of lines & $\mathrm{km}$ & 115 & 8218.09 & 275 & 33708 & 8932.64 \\
\hline $\mathbf{x}_{\mathbf{2}}$ & No. of employees & $\begin{array}{l}\text { Person } \\
\left(\times 10^{3}\right)\end{array}$ & 115 & 43.13 & 1.1 & 294 & 60.94 \\
\hline $\mathbf{x}_{\mathbf{3}}$ & $\begin{array}{l}\text { No. of passenger } \\
\text { cars }\end{array}$ & Cars & 115 & 4484.21 & 77 & 29470 & 6501.19 \\
\hline $\mathbf{x}_{\mathbf{4}}$ & $\begin{array}{l}\text { No. of freight } \\
\text { wagons }\end{array}$ & Wagons & 115 & 20568.10 & 1007 & 113657 & 23258.22 \\
\hline $\boldsymbol{y}_{\mathbf{1}}$ & $\begin{array}{l}\text { Passenger- } \\
\text { Kilometers }\end{array}$ & $\begin{array}{l}\text { Person } \times \mathrm{km} \\
\left(\times 10^{6}\right)\end{array}$ & 115 & 13926.96 & 99 & 86094 & 23084.12 \\
\hline $\boldsymbol{y}_{\mathbf{2}}$ & $\begin{array}{l}\text { Freight Ton- } \\
\text { Kilometers }\end{array}$ & $\begin{array}{l}\text { Ton } \times \mathrm{km} \\
\left(\times 10^{6}\right)\end{array}$ & 115 & 14608.66 & 189 & 111980 & 22324.52 \\
\hline
\end{tabular}

\subsection{Mathematical formulation of DEA model}

In order to obtain consistent technical efficiency scores, appropriate DEA model must be defined. Regarding the orientation of model, form of identified technical efficiency and the assumption of return to scale, this paper employs input oriented DEA model with constant return to scale (see Oum and Yu, 1994; Hilmola, 2008), and considers Pareto-Koopmans technical efficiency. Although Coelli \& Perelman (2000) stated that the choice of orientation of the distance function is not as important in case of railway companies as for other industries, this paper employs input orientated model, assuming that the railway companies have a higher influence on the inputs than on the outputs (Merkert et al., 2009).

Based on work of Farell (1957), who introduced basic idea and definition of DEA, Charnes et al. (1978) developed linear programming (CCR DEA) model. Input oriented CCR DEA model employed in this paper has the following form: 


$$
(\max ) h_{k}=\sum_{r=1}^{s} u_{r} y_{r k}
$$

With constraints:

$$
\begin{gathered}
\sum_{i=1}^{m} v_{i} x_{i k}=1 \\
\sum_{r=1}^{s} u_{r} y_{r j}-\sum_{i=1}^{m} v_{i} x_{i j} \leq 0, \quad j=1, \ldots, n \\
u_{r}>0, \quad r=1, \ldots, s \\
v_{i}>0, \quad i=1, \ldots, m
\end{gathered}
$$

One of the main drawbacks of previous DEA model is that it is not able to make a difference in efficiency level of efficient units, since all efficient units have efficiency score equal 1. To rectify this shortcoming, Andersen \& Petersen (1993) introduced super-efficiency grade and showed that the CCR model can be modified for the purpose of ranking units. The modification is leaving out the unit for which the efficiency is measured in the constraints set (3), so it becomes (8). The DEA model in this case has the following form:

$$
(\max ) h_{k}=\sum_{r=1}^{s} u_{r} y_{r k}
$$

With constraints:

$$
\begin{gathered}
\sum_{i=1}^{m} v_{i} x_{i k}=1 \\
\sum_{r=1}^{s} u_{r} y_{r j}-\sum_{i=1}^{m} v_{i} x_{i j} \leq 0, \quad j=1, \ldots, n ; \quad j \neq k \\
u_{r}>0, \quad r=1, \ldots, s \\
v_{i}>0, \quad i=1, \ldots, m
\end{gathered}
$$

\subsection{Efficiency scores of European railway companies}

Using data defined above, models (1)-(5) and (6)-(10) are solved for each year of the time period observed, and the technical efficiency (TE) and super efficiency (SE) scores are obtained. Models (1)-(5) and (6)-(10) are solved using $\mathrm{EMS}^{3}$ software. TE and SE scores are presented in Table 3.

Best performance during the period observed showed companies from Spain, Switzerland, Lithuania, France and Belarus, and they represent benchmarks for other railway companies. Also, high efficiency level (above $80 \%$ efficiency level in average) showed companies from Austria, Finland, Germany, Italy and Portugal. Lowest performance (below 30\% efficiency level in average) showed railway companies from Moldova and Serbia. 
Table 3: Efficiency scores of European railway companies for period 2009-2013

\begin{tabular}{|l|c|c|c|c|c|c|c|c|c|c|}
\hline \multirow{2}{*}{ Comp. } & \multicolumn{2}{|c|}{2009} & \multicolumn{2}{|c|}{2010} & \multicolumn{2}{c|}{2011} & \multicolumn{2}{c|}{2012} & \multicolumn{2}{c|}{2013} \\
\cline { 2 - 11 } & TE & SE & TE & SE & TE & SE & TE & SE & TE & SE \\
\hline OBB & 0.853 & & 0.850 & & 0.923 & & 1.000 & 1.063 & 0.993 & \\
\hline BC & 1.000 & 1.279 & 1.000 & 1.453 & 1.000 & 1.242 & 1.000 & 1.293 & 1.000 & 1.236 \\
\hline SNCB & 0.654 & & 0.562 & & 0.716 & & 0.741 & & 0.706 & \\
\hline BDZ & 0.386 & & 0.274 & & 0.307 & & 0.304 & & 0.543 & \\
\hline HZ & 0.764 & & 0.407 & & 0.375 & & 0.452 & & 0.421 & \\
\hline CD & 0.380 & & 0.431 & & 0.464 & & 0.515 & & 0.528 & \\
\hline VR & 0.948 & & 0.896 & & 0.923 & & 0.971 & & 1.000 & 1.165 \\
\hline SNCF & 1.000 & 1.615 & 1.000 & 1.746 & 1.000 & 2.045 & 1.000 & 2.245 & 1.000 & 2.068 \\
\hline DBAG & 0.758 & & 0.767 & & 0.776 & & 0.818 & & 1.000 & 1.042 \\
\hline FS & 0.934 & & 0.773 & & 0.839 & & 0.807 & & 0.852 & \\
\hline LG & 1.000 & 1.922 & 1.000 & 3.021 & 1.000 & 3.906 & 1.000 & 3.836 & 1.000 & 3.900 \\
\hline CFL & 0.365 & & 0.246 & & 0.347 & & 0.381 & & 0.370 & \\
\hline MZ & 0.390 & & 0.317 & & 0.338 & & 0.338 & & 0.389 & \\
\hline CFM & 0.238 & & 0.173 & & 0.223 & & 0.199 & & 0.236 & \\
\hline PKP & 0.551 & & 0.410 & & 0.474 & & 0.475 & & 0.496 & \\
\hline CP & 0.716 & & 1.000 & 2.775 & 1.000 & 3.530 & 1.000 & 3.183 & 0.848 & \\
\hline CFR & 0.440 & & 0.302 & & 0.330 & & 0.299 & & 0.351 & \\
\hline ZS & 0.233 & & 0.229 & & 0.247 & & 0.212 & & 0.236 & \\
\hline ZSSK & 0.485 & & 0.500 & & 0.502 & & 0.531 & & 0.553 & \\
\hline SZ & 0.548 & & 0.624 & & 0.632 & & 0.655 & & 0.758 & \\
\hline RENFE & 1.000 & 2.064 & 1.000 & 1.616 & 1.000 & 1.630 & 1.000 & 1.755 & 1.000 & 1.817 \\
\hline SBB & 1.000 & 1.934 & 1.000 & 1.866 & 1.000 & 1.838 & 1.000 & 1.801 & 1.000 & 1.866 \\
\hline TCDD & 0.989 & & 0.522 & & 0.489 & & 0.466 & & 0.642 & \\
\hline
\end{tabular}

Using TE and SE scores obtained, ranking of railway companies is conducted (Figure 2). The highest yearto-year rank difference during the period observed showed companies from Portugal, Turkey and Croatia. Except companies from Lithuania, France, Croatia, Germany, Romania and Macedonia, there are no clear trends in ranking of railways, in terms of constant rank improvement or worsening during the period observed.

Figure 2: Ranking of European railway companies for period 2009-2013

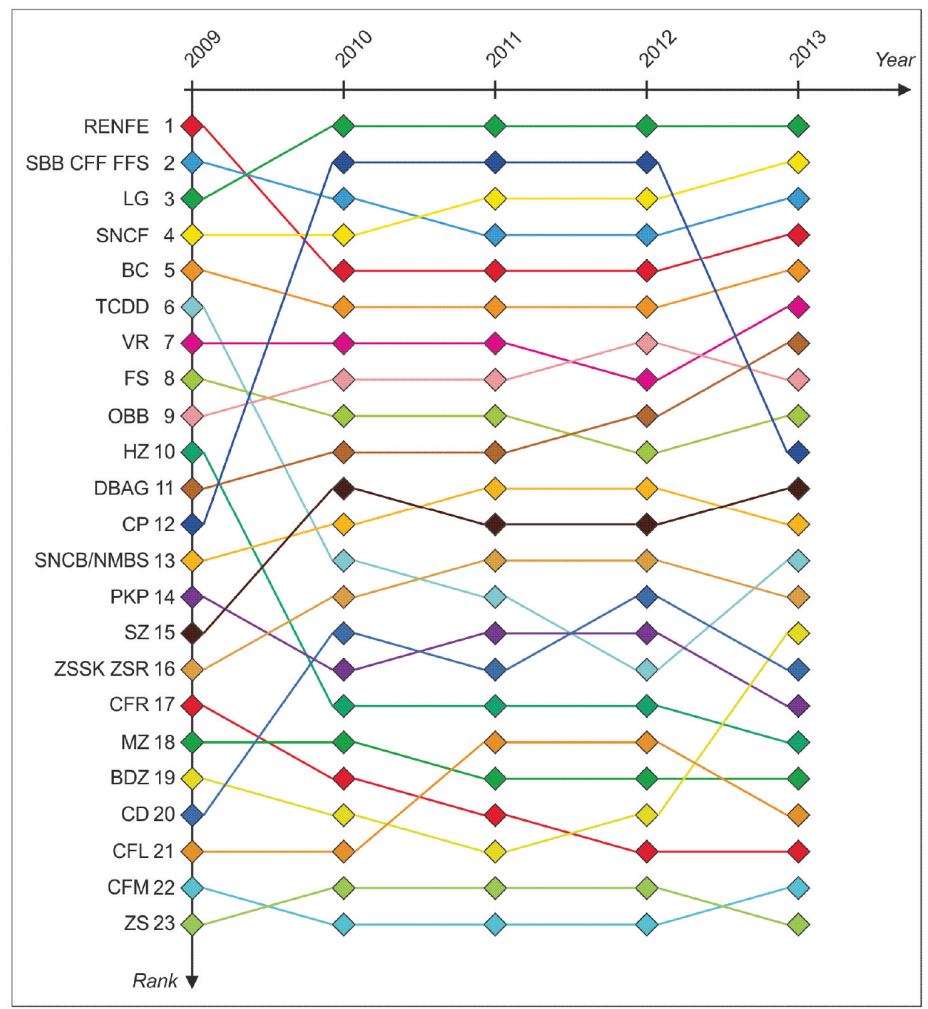




\section{Analysis of innovations impact on European railway companies efficiency}

This paper investigates impact of two types of innovations on railways efficiency level - technological innovations and innovations in terms of structural and regulatory reforms. Using technical efficiency scores obtained in the previous stage, this stage introduces additional innovation indicators and conducts different statistical tests.

\subsection{Impact of technological innovations on railways efficiency level}

In order to obtain a unique European railway transport market, one of the main goals is to provide railway interoperability across Europe. Increased cross-border traffic is faced with different signaling and control systems from country to country, as a consequence of different manufacturers. In order to respond this challenge, European Commission (EC) initiated development of new signaling and control system. Directive 96/48/EC enforces "the ability of the Trans-European high-speed rail system to allow the safe and uninterrupted movement of high-speed trains which accomplish the specified levels of performance" (Council Directive, 1996). As a consequence, project called European Rail Traffic Management System (ERTMS) has been established. The ERTMS system is composed of two main components: European Train Control System (ETCS), implemented, in part, onboard trains and partly as a fixed infrastructure, and GSM-R, which is the communication system between the ETCS onboard subsystem and the ETCS trackside subsystem (Ghazel, 2014). The ERTMS is constantly evolving and many countries are gradually introducing this system.

In order to analyze the impact of ERTMS implementation on technical efficiency of railway companies, Tobit regression (Tobin, 1958) is used in this stage. When the efficiency scores calculated by DEA are used as dependent variables in regression, we find a good example of censoring, which means that the values of the dependent variable (TE in our case) are limited to a range of values (between 0 and 1). More precisely, censoring occurs when the dependent variable is observed as a subsample, while information about independent variables for the entire sample is available. This is why the Tobit regression (also known as the censored regression) has been widely used to determine the efficiency drivers of railway companies (e.g. Oum \& Yu, 1994; Merkert et al., 2009; Nashand \& Nash, 2010; Kutar et al., 2013).

Using TE scores as dependent variable, two different explanatory variables, representing ERTMS implementation are defined - percentage of lines equipped with ERTMS, and percentage of vehicles equipped with ERTMS. Considering large differences in absolute values (length of lines and number of vehicles) from country to country, these ratio indicators are used as most adequate. Only projects implemented before or during the time period observed are taken into account. Data are obtained from the official ERTMS deployment statistics ${ }^{4}$. In addition, three additional explanatory variables, representing infrastructure development are introduced. These variables include network density, percentage of doubletrack lines and percentage of electrified lines. Descriptive statistics of variables used in Tobit regression are presented in Table 4.

Table 4: Descriptive statistics of variables in Tobit regression

\begin{tabular}{|l|l|l|c|c|c|c|c|}
\hline Var. & \multicolumn{1}{|c|}{ Description } & \multicolumn{1}{c|}{ Unit } & Obs. & Mean & Min & Max & Std.Dev. \\
\hline$T E$ & Technical efficiency & - & 115 & 0.660052 & 0.173 & 1 & 0.285763 \\
\hline$z_{1}$ & Network density & $\mathrm{km} / \mathrm{km}^{2}$ & 115 & 0.055621 & 0.011286 & 0.123482 & 0.030833 \\
\hline$z_{2}$ & $\begin{array}{l}\text { Percentage of double-track } \\
\text { lines }\end{array}$ & $\%$ & 115 & 49.64953 & 0 & 100 & 25.1595 \\
\hline$z_{3}$ & $\begin{array}{l}\text { Percentage of electrified } \\
\text { lines }\end{array}$ & $\%$ & 115 & 29.4834 & 0 & 77.75294 & 19.18845 \\
\hline$z_{4}$ & $\begin{array}{l}\text { Percentage of lines equipped } \\
\text { with ERTMS }\end{array}$ & $\%$ & 115 & 2.225403 & 0 & 38.79262 & 7.276728 \\
\hline$z_{5}$ & $\begin{array}{l}\text { Percentage of vehicles } \\
\text { equipped with ERTMS }\end{array}$ & $\%$ & 115 & 3.316203 & 0 & 82.81853 & 12.69245 \\
\hline
\end{tabular}


Results of Tobit regression are presented in Table 5. Tobit regression, as well all other statistical tests in this paper are conducted using Stata software ${ }^{5}$. Regarding network density, results showed statistically significant negative impact on technical efficiency of railway companies. It could be explained as a consequence of excessive engagement of input variable (length of lines) by railway companies. Variable regarding percentage of double-track lines showed negative impact on efficiency, although it has no statistical significance. Variables which represent percentage of electrified lines and percentage of lines equipped with ERTMS showed statistically significant and positive impact on efficiency, as expected. Variable which represents percentage of vehicles equipped with ERTMS showed statistically significant and negative impact on railways efficiency, which could be explained with reduced sample of railway companies in this study, considering that some omitted companies are large ERTMS users.

Table 5: Results of Tobit analysis

\begin{tabular}{|l|c|c|}
\hline \multicolumn{1}{|c|}{ Variable } & Coefficient & t-ratio \\
\hline$z_{1}$ & $-7.810897^{\star \star}$ & -6.49 \\
\hline$z_{2}$ & -0.002507 & -1.49 \\
\hline$z_{3}$ & $0.016739^{\star \star}$ & 6.64 \\
\hline$z_{4}$ & $0.025803^{\star \star}$ & 3.44 \\
\hline$z_{5}$ & $-0.010601^{\star}$ & -2.51 \\
\hline Constant & $0.760149^{\star \star}$ & 10.52 \\
\hline Sigma & 0.282205 & \\
\hline Pseudo R2 & 0.4440 & \\
\hline Log Likelihood & -37.032108 & \\
\hline Number of observations & 115 & \\
\hline Uncensored observations & 84 & \\
\hline Censored observations & 31 & \\
\hline
\end{tabular}

*Denotes statistical significance at level $\alpha=5 \%$

**Denotes statistical significance at level $\alpha=1 \%$

The implementation of ERTMS contributes to uninterrupted cross-border traffic, by overcoming abovementioned problems of different signaling and control systems between countries. This allows increased volume of transit traffic, which in most countries has a significant share in the total traffic volume. Also, the implementation of ERTMS contributes to removing bottlenecks and improving trains performance, thus enabling railways to meet increased transport demand.

In order to analyze difference in efficiency level of railway companies which implemented ERTMS and those which did not, next hypothesis is set:

Hypothesis 1: There is a difference in efficiency scores of railway companies which implemented ERTMS and those which did not, and companies which implemented ERTMS have higher efficiency level, as a consequence of increased traffic flow.

The previous hypothesis was tested using non-parametric Man-Whitney and Kolmogorov-Smirnof tests. Results of Mann-Whitney test (Table 6) showed that there are statistically significant differences between these two groups, and that the companies which implemented ERTMS have higher efficiency scores. Thus the null hypothesis is rejected, and Hypothesis 1 is accepted. Results of Kolmogorov-Smirnof test (Table 7) confirmed this conclusion. 
Table 6: Results of Mann-Whitney test - ERTMS implementation

\begin{tabular}{|l|c|c|c|}
\hline ERTMS implemented & Observations & Rank sum & Expected \\
\hline No & 77 & 3929.5 & 4466 \\
\hline Yes & 38 & 2740.5 & 2204 \\
\hline Combined & 115 & 6670 & 6670 \\
\hline Unadjusted variance & 28284.67 & & \\
\hline Adjustment for ties & -554.07 & & \\
\hline Adjusted variance & 27730.60 & & \\
\hline$Z$ & -3.222 & & \\
\hline$p$-value $(\alpha=0.05)$ & 0.0013 & & \\
\hline
\end{tabular}

Table 7: Results of Kolmogorov-Smirnof test - ERTMS implementation

\begin{tabular}{|l|c|c|}
\hline \multicolumn{1}{|c|}{ Smaller group } & D & P-value \\
\hline No & 0.4012 & 0.0000 \\
\hline Yes & 0.0000 & 1.0000 \\
\hline Combined & 0.4012 & 0.0001 \\
\hline Observations & 115 & \\
\hline Unique values & 80 & \\
\hline
\end{tabular}

\subsection{Impact of structural and regulatory reforms on railways efficiency level}

Railway reform in EU began in 1991 with the EC directive 91/440/EEC aiming to facilitate the creation of Single Market and to increase railways efficiency. The four main objectives are related to: (i) insuring the independent management of railway undertakings (operators); (ii) separating the management of railway operations and infrastructure from the provision of transport services; (iii) improving the financial structure of the undertakings; (iv) ensure international access to the networks of Member states for international combined transport of goods (Council Directive, 1991). Licencing issues were subject of the following Directive 95/18/EC (Council Directive, 1995). After that, a set of four "railway packages" and complementary initiatives were brought by EC in the early 2000s. An essential goal of the rail reforms in the EU was to improve the efficiency and competitiveness of the European railway system and in the end to increase its market share in the modal split (Grushevska et al., 2016).

Two different indicators regarding structural and regulatory reforms implementation are considered in this paper - the implementation of vertical separation and the implementation of horizontal separation. Following the UIC classification, there are five categories of railway organizations: (1) integrated company, (2) railway undertaking (i.e. passenger and freight operators), (3) passenger operator, (4) freight operator, and (5) infrastructure manager. Based on this classification, the vertically integrated company represents a company providing rail operations while holding its own infrastructure, while the vertically separated company is a company comprised of a railway undertaking and an infrastructure manager (Mizutani \& Uranishi, 2013). Horizontally separated company is a company (railway undertaking) which separated its passenger and freight operations.

Although there are different types of vertical separation (Vešović \& Bojović, 2002), in this study, only vertical separation at the institutional level is considered, meaning that two different organizations held by the same holding company are not observed as separated organizations. Therefore, in this paper, vertical separation means that the rail operations and infrastructure management activities are performed by completely separated companies. The same principle goes for horizontal separation. Data related to the implementation of vertical and horizontal separation of railway companies are gathered from different studies (Sanchez et al., 2008; Wolff, 2011; Mizutani \& Uranishi, 2013; Mizutani et al., 2014), and also from respective companies annual reports. The implementation of vertical and horizontal separation during the period observed is presented in Table 8. 
Table 8: The implementation of vertical and horizontal separation during the period 2009-2013

\begin{tabular}{|c|c|c|c|}
\hline Country & Abbreviation & Vertical separation & Horizontal separation \\
\hline Austria & OBB & No & No \\
\hline Belarus & $\mathrm{BC}$ & No & No \\
\hline Belgium & SNCB/NMBS & No & No \\
\hline Bulgaria & $\mathrm{BDZ}$ & Yes & No \\
\hline Croatia & $\mathrm{HZ}$ & No & No \\
\hline Czech Republic & $\mathrm{CD}$ & Yes & No \\
\hline Finland & VR & Yes & No \\
\hline France & SNCF & Yes & No \\
\hline Germany & DBAG & No & No \\
\hline Italy & FS & No & No \\
\hline Lithuania & LG & No & No \\
\hline Luxembourg & CFL & No & Yes \\
\hline Macedonia & $\mathrm{MZ}$ & No & No \\
\hline Moldova & CFM & No & No \\
\hline Poland & PKP & No & No \\
\hline Portugal & $\mathrm{CP}$ & Yes & No \\
\hline Romania & CFR & No & No \\
\hline Serbia & ZS & No & No \\
\hline Slovak Republic & ZSSK ZSR & Yes & Yes \\
\hline Slovenia & SZ & No & No \\
\hline Spain & RENFE & Yes & No \\
\hline Switzerland & SBB CFF FFS & No & No \\
\hline Turkey & TCDD & No & No \\
\hline
\end{tabular}

In order to analyze difference in efficiency level of railway companies which conducted vertical separation and those which did not, next hypothesis is set:

Hypothesis 2: There is a difference in efficiency scores of railway companies which conducted vertical separation and those which did not, and companies which conducted vertical separation have higher efficiency level, as a consequence of different business environment.

Both, Man-Whitney (Table 9) and Kolmogorov-Smirnof test (Table 10) showed that there is statistically significant difference in efficiency scores between these two groups, and that railway companies which conducted vertical separation have higher efficiency level. Thus, null hypothesis is rejected, and Hypothesis 1 is accepted.

Table 9: Results of Mann-Whitney test - Vertical separation

\begin{tabular}{|l|c|c|c|}
\hline \multicolumn{1}{|c|}{ Vertical separation } & Observations & Rank sum & Expected \\
\hline No & 80 & 4273 & 4640 \\
\hline Yes & 35 & 2397 & 2030 \\
\hline Combined & 115 & 6670 & 6670 \\
\hline Unadjusted variance & 27066.67 & & \\
\hline Adjustment for ties & -530.21 & & \\
\hline Adjusted variance & 26536.46 & & \\
\hline$Z$ & -2.253 & & \\
\hline$p$-value $(\alpha=0.05)$ & 0.0243 & & \\
\hline
\end{tabular}


Table 10: Results of Kolmogorov-Smirnof test - Vertical separation

\begin{tabular}{|l|c|c|}
\hline \multicolumn{1}{|c|}{ Smaller group } & D & P-value \\
\hline No & 0.2518 & 0.046 \\
\hline Yes & 0.0000 & 1.000 \\
\hline Combined & 0.2518 & 0.091 \\
\hline Observations & 115 & \\
\hline Unique values & 80 & \\
\hline
\end{tabular}

In addition, in order to analyze difference in efficiency level of railway companies which conducted horizontal separation and those which did not, next hypothesis is set:

Hypothesis 3: There is a difference in efficiency scores of railway companies which conducted horizontal separation and those which did not, and companies which conducted horizontal separation have higher efficiency level, as a consequence of different business environment.

Results of Man-Whitney test (Table 11), as well as of Kolmogorov-Smirnof test (Table 12) showed that there is statistically significant difference in efficiency scores between these two groups, and that railway companies which conducted horizontal separation have lower efficiency scores. Thus, both null hypothesis and Hypothesis 3 are rejected. This could be explained with the fact that many companies have conducted vertical separation, but are still operating as a single passenger and freight operator, or they have conducted horizontal separation at the accounting level. Also, some of companies omitted in the analysis represent best practice in reforms implementation.

Table 11: Results of Mann-Whitney test - Horizontal separation

\begin{tabular}{|l|c|c|c|}
\hline \multicolumn{1}{|c|}{ Vertical separation } & Observations & Rank sum & Expected \\
\hline No & 105 & 6333 & 6090 \\
\hline Yes & 10 & 337 & 580 \\
\hline Combined & 115 & 6670 & 6670 \\
\hline Unadjusted variance & 10150.00 & & \\
\hline Adjustment for ties & -198.83 & & \\
\hline Adjusted variance & 9951.17 & & \\
\hline$Z$ & 2.436 & & \\
\hline$p$-value $(\alpha=0.05)$ & 0.0149 & & \\
\hline
\end{tabular}

Table 12: Results of Kolmogorov-Smirnof test - Horizontal separation

\begin{tabular}{|l|c|c|}
\hline \multicolumn{1}{|c|}{ Smaller group } & D & P-value \\
\hline No & 0.0857 & 0.874 \\
\hline Yes & -0.5905 & 0.002 \\
\hline Combined & 0.5905 & 0.003 \\
\hline Observations & 115 & \\
\hline Unique values & 80 & \\
\hline
\end{tabular}




\section{Conclusion}

This paper analyzes impact of innovations on technical efficiency of European railway companies. The evaluation of efficiency and ranking of 23 national railway companies was conducted using DEA method, observing time period from 2009 to 2013. Using four input and two output variables which characterize railway transportation process, technical efficiency scores are obtained by solving input oriented CCR DEA model. The ranking of railway companies is successfully conducted using modified DEA model, which enables ranking of efficient companies by introducing super efficiency scores. This approach provided the observation of efficiency and ranking trends of railway companies during the period observed.

In the second stage of the study, different factors representing technological and organizational innovations in railway sector are introduced. Variables representing technological innovations consider implementation of European Rail Traffic Management System (ERTMS), and include percentage of lines and vehicles equipped with ERTMS. Also three additional variables, which represent infrastructure development are introduced. These include network density, and percentage of double-track and electrified lines. The impact of these explanatory variables on railways efficiency was analyzed using Tobit regression. In addition, the hypothesis testing was conducted aiming to observe the difference between railway companies which implemented ERTMS, and those which did not. Results showed that railway companies which implemented ERTMS have higher efficiency level. Considering structural reform and railways industrial restructuring, hypothesis testing was conducted with the aim to analyze the difference in efficiency level between companies which conducted vertical and horizontal separation, and those which did not. Results showed that companies which separated infrastructure management and transport operations have higher efficiency level. Regarding horizontal separation, it has been shown that companies which conducted horizontal separation have lower efficiency scores.

Overcome of the problem of lack of data for some companies would enable larger sample analysis. Also, future research directions are including some private railway operators in the analysis, as well as observing differences in passenger and freight transportation service. In addition, inefficiency aspect of companies will be analyzed in DEA, in terms of efficiency improvement possibility by reduction of some inputs.

\section{Acknowledgement}

This work was partially supported by Ministry of Education, Science and Technological Development, Republic of Serbia, through the project TR36022.

\section{REFERENCES}

[1] Andersen, P., \& Petersen, N.C. (1993). A Procedure for Ranking Efficient Units in Data Envelopment Analysis. Management Science, 39 (10), 1261-4.

[2] Charnes, A., Cooper, W.W., \& Rhodes, E. (1978). Measuring Efficiency of Decision Making Units. European Journal of Operational Research, 2, 429-444.

[3] Coelli, T., \& Perelman, S. (2000). Technical efficiency of European railways: a distance function approach. Applied Economics, 32(15), 1967-1976.

[4] Council Directive 91/440/EEC of 29 July 1991 on the development of the Community's railways. Official Journal L 237, 24/08/1991, 25-28.

[5] Council Directive 95/18/EC of 19 June 1995 on the licensing of railway undertakings. Official Journal L 143, 27/06/1995, 70-74.

[6] Council Directive 96/48/EC of 23 July 1996 on the Interoperability of the Trans-European High-Speed Rail System. Official Journal of the European Union L 235, 17/09/1996, 6-24.

[7] Farrell, M.J. (1957). The Measurement of Productive Efficiency. Journal of the Royal Statistical Society. Series A (General), 120(3), 253-290.

[8] Ghazel, M. (2014). Formalizing a subset of ERTMS/ETCS specifications for verification purposes. Transportation Research Part C, 42, 60-75.

[9] Grushevska, K., Notteboom, T, \& Shkliar, A. (2016). Institutional rail reform: The case of Ukrainian Railways. Transport Policy 46, 7-19. 
[10] Hilmola, O-P. (2008). Railway efficiency analysis from larger Europe during the period 1994-2003. Int. J. Operational Research, 3(3), 255-280.

[11] Kutlar, A., Kabasakal, A., \& Sarikaya, M. (2013). Determination of the efficiency of the world railway companies by method of DEA and comparison of their efficiency by Tobit analysis. Quality \& Quantity, 47, 3575-3602.

[12] Liu, J.S., Lu L.Y.Y., \& Lu, W-M. (2016). Research fronts in data envelopment analysis. Omega. International Journal of Management Science, 58, 33-45.

[13] Liu, J.S., Lu, L.Y.Y., Lu, W-M., \& Lin, B.J.Y. (2013a). Data envelopment analysis 1978-2010: A citationbased literature survey. Omega, International Journal of Management Science, 41, 3-15.

[14] Liu, J.S., Lu, L.Y.Y., Lu, W-M., \& Lin, B.J.Y. (2013b). A survey of DEA applications. Omega, International Journal of Management Science, 41, 893-902.

[15] Merkert, R., Smith, A., \& Nash, C. (2009). The institutional, environmental and transactional factors on train operating company performance - A Tobit regression approach based on DEA efficiency scores. European Transport Conference, Noordwijkerhout, Netherlands.

[16] Mizutani, F., \& Uranishi, S. (2013). Does vertical separation reduce cost? An empirical analysis of the rail industry in European and East Asian OECD Countries. J Regul Econ, 43, 31-59.

[17] Mizutani, F., Smith, A., Nash, C., \& Uranishi, S. (2014). Comparing the Costs of Vertical Separation, Integration, and Intermediate Organisational Structures in European and East Asian Railways. Discussion Paper Series, Kobe University, Graduate School of Business Administration, Japan.

[18] Nashand, A.S.J., \& Nash, C.A. (2010). Benchmarking of train operating firms: a transaction cost efficiency analysis. Transp. Plan. Technol., 33(1), 35-53.

[19] Oum, T.H., \& Yu, C. (1994). Economic Efficiency of Railways and Implications for Public Policy. Journal of Transport Economics and Policy, 18(2), 121-138.

[20] Sanchez, P.C., Monsalvez, J.M.P., \& Matrinez, L.S. (2008). Vertical and Horizontal Separation in the European Railway Sector: Effects on Productivity. Working Paper, BBVA Foundation.

[21] Tobin, J. (1958). Estimation of relationships for limited dependent variables. Econometrica, 26, 24-36.

[22] Vešović, V.B., \& Bojović, N.J., (2002). Organizacija saobraćajnih preduzeća. Saobraćajni fakultet, Beograd.

[23] Wolff, J.W., (2011). Organizational Structures \& Performance Evaluation of Railways: Based on European railway reform experiences and applied to Israel Railways. Master Thesis, Delft University of Technology, Netherlands.

[24] Yu, M.M., \& Lin T.J.E. (2008). Efficiency and effectiveness in railway performance using a multi-activity network DEA model. Omega - International Journal of Management Science, 36(6), 1005-1017.

Receieved: January 2016. Accepted: May 2016. 


\section{$1 / 1 / 1 / 1 / 1 / 1 / 1 / 1 / 1 / 1 / 1 / 1 / 1 / 1 / 1 / /$ abouthe euthor}

\section{Nebojša Bojović \\ University of Belgrade, Faculty of Transport and Traffic Engineering, Serbia E-mail: nb.bojovic@sf.bg.ac.rs}

Nebojša Bojović, PhD is a dean and a full professor at the Faculty of Transport and Traffic Engineering, University of Belgrade. He is an author and co-author of several books and more than 40 scientific papers. Prof. Bojović is a reviewer at several international scientific journals, "Transportation Research part B", "Transportation Research part E", "European Journal of Operational Research", "Computational and Mathematical Organization Theory", "Annals of Operations Research", "Journal of Applied Mathematics and Decision Sciences". His professional expertise, research and teaching interests include: Applications of Operations Research, Information Systems and Control Theory in Transportation Systems with particular emphasis on: Rail freight car fleet sizing, Railway vehicle routing and scheduling, Risk management and Project management.

\section{Miloš Milenković University of Belgrade, Faculty of Transport and Traffic Engineering, Serbia Zaragoza Logistic Center E-mail:m.milenkovic@sf.bg.ac.rs; mimilenkovic@zlc.edu.es}

Milos Milenkovic is Assistant Professor at The Faculty of Transport and Traffic Engineering, University of Belgrade, Serbia and a Research Fellow at the MIT-Zaragoza International Logistics Program. Dr. Milenkovic's main research areas are mathematical optimization, model predictive control theory, time series analysis, project management and engineering economy with a special focus on transport related applications. He is engaged as a member of editorial board of a number of scientific conferences and also as a reviewer of a number of prestigious peer-reviewed journals, like "International Journal of Uncertainty, Fuzziness and Knowledge-Based Systems", "Applied Mathematical Modelling" and "Transportation Research Part E". During his career Dr Milenkovic published more than forty papers in journals as well as on scientific conferences.

Marko Kapetanović University of Belgrade, Faculty of Transport and Traffic Engineering, Serbia E-mail: marko.kapetanovic@live.com

Marko Kapetanović, MSc is student of doctoral studies and research assistant at the Faculty of Transport and Traffic Engineering, University of Belgrade. He graduated and earned his Master's degree from the Railways Transport and Traffic Engineering Department, at the Faculty of Transport and Traffic Engineering, University of Belgrade. He is an author and coauthor of two scientific papers in proceedings of domestic and international scientific conferences. His research area of interests include application of operational research in transportation systems, transport economics and revenue management.

\section{Nikola Knežević \\ University of Belgrade, Faculty of Transport and Traffic Engineering, Serbia E-mail: n.knezevic@sf.bg.ac.rs}

Nikola Knežević, PhD, is an assistant professor at the Faculty of Transport and Traffic Engineering, University of Belgrade, Serbia. His areas of academic interest include: project management, organization design, performance management and application of quantitative methods in management. He is author and co-author of one book and over 40 papers published in scientific journals and at scientific conferences. He was a reviewer of one book (monograph). In his previous career, he was engaged by the Government of the Republic of Serbia in the Development Strategy of postal services, and by the Government of Montenegro in the Development Strategy of postal traffic.
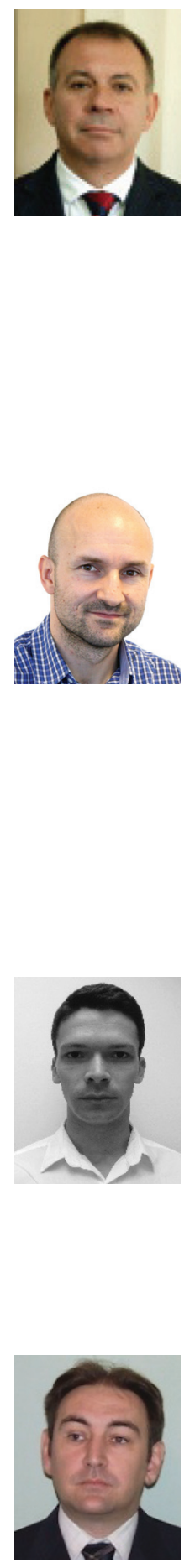